Departamento de Historia Universidad de Santiago de Chile

Revista de Historia Social $\mathrm{y}$ de las Mentalidades

Volumen 24, $\mathrm{N}^{\circ}$ 2, 2020: 41-68

Issn Online: 0719-4749

\title{
O COTIDIANO DA ATUAÇÃO DO VIGÁRIO DA VARA NA COMARCA DO SERRO DO FRIO, MINAS GERAIS, 1714-1821*
}

\author{
THE DAILY PERFORMANCE OF THE ARCHPRIEST IN THE SERRO DO FRIO COUNTY, \\ MINAS GERAIS, 1714-1821
}

DR. DANILO ARNALDO BRISKIEVICZ**

IFMG - Instituto Federal de Minas Gerais, campus Santa Luzia

Belo Horizonte, Brasil

Email: doserro@hotmail.com

Id-ORCID: 0000-0002-7652-1959

\begin{abstract}
RESUMO
Analisa-se o papel do vigário da vara no cotidiano das relações sociais da Comarca do Serro do Frio, na Capitania de Minas Gerais. Demonstram-se os mecanismos de atuação do vigário da vara a partir do Regimento do Auditório (1704), originados pela queixa formal de um reclamante, a confecção das partes do processo com oitivas de testemunhas e o encaminhamento para o vigário-geral e para o bispo diocesano. A metodologia de investigação é a pesquisa bibliográfica e de documentos brasileiros e portugueses. $\mathrm{O}$ resultado da pesquisa surge nas etapas da narrativa; explicamos a atuação do vigário da vara de maneira cronológica, demonstrando como essa figura estruturava em torno de si o poder moralizador da Igreja católica.

Palavras-chave: Brasil colônia; Padroado real; vigário da vara; Comarca do Serro do Frio
\end{abstract}

\begin{abstract}
The role of the archpriest in the daily life of the social relations of the Serro do Frio District, in the Captaincy of Minas Gerais, is analyzed. The archpriest's mechanisms of action are demonstrated based on the Rules of the Auditorium (1704), originated by the formal complaint of a claimant, the preparation of the process steps with hearings of witnesses and the referral to the vicar general and to the diocesan bishop. The methodology of this work consists of a bibliographic and documentary research on Brazilian and Portuguese documents. The results of the study appear in the narrative stages of the same. The work of the archpriest is explained in a chronological way, demonstrating how this figure structured around him the moralizing power of the Catholic Church.
\end{abstract}

Keywords: Brazil Colony; Royal Patronage; Archpriest Serro do Frio County

* $\quad$ Recibido: 12 de agosto de 2020; Aprobado: 2 de noviembre de 2020.

** Produção pessoal, artigo de pesquisa. Parte da pesquisa desenvolvida em torno da história política da Comarca do Serro do Frio, Minas Gerais, Brasil. 


\section{INTRODUÇÃO}

A primeira diocese brasileira foi o Arcebispado do Bahia, com sede em Salvador, criada em 25 de fevereiro de 1551 e que se tornou a primaz do Brasil em 16 de novembro de 1676. Em Salvador funcionavam o Arcebispado da Bahia enquanto sede do poder eclesiástico brasileiro e o Governo-geral do Brasil enquanto sede do poder político da coroa portuguesa na colônia. A Diocese do Rio de Janeiro foi criada em 16 de novembro de 1676, sufragânea ao Arcebispado da Bahia, ou seja, dependente e subordinada à sua primaz. As minas do Serro do Frio (em 1714, Vila do Príncipe e em 1838 cidade do Serro) quando foram descobertas pelos bandeirantes paulistas em 1702 já pertenciam à Diocese do Rio de Janeiro formalmente sendo que depois de disputas pelo território com o Arcebispado da Bahia ficaram definidos seus limites, sendo o extremo norte do atual estado de Minas Gerais pertencente aos arcebispos baianos e seu clero. Somente em 1745 foi criada a Diocese de Mariana a qual pertenceu a paróquia de Nossa Senhora da Conceição da Vila do Príncipe e seu termo até 1863, com a criação da Diocese de Diamantina.

O que é importante para nosso estudo é forma de organização das hierarquias dentro do sistema do padroado real. Dessa forma, havia no período colonial duas fontes de poder que operavam simultaneamente na vida do indivíduo nas minas do Serro do Frio e sua Vila do Príncipe:

a. a Coroa portuguesa mandava em seu território, o Brasil, dividido em capitanias, estas com uma capital (a Capitania de Minas Gerais tinha a capital Vila Rica), e organizada em sucessivas comarcas (a do Serro do Frio foi a quarta mineira) com sua cabeça ou capital (a Vila do Príncipe em relação à sua comarca), que obrigatoriamente tinha sua ouvidoria (comarca e ouvidoria são praticamente sinônimos) instalada em sua capital ou cabeça, que recebia a instalação de seu Senado da Câmara para administrar o seu termo realizando obras, expedindo ordens, governando seu termo com vereações e corpo administrativo próprio; por outro lado, a comarca com seu ouvidor governava o seu território aplicando a justiça, com corpo administrativo próprio, com seus funcionários e edifício específicos;

b. a Igreja mandava em seu território, a diocese, dividida em paróquias ou freguesias compostas por número de fiéis e número de fogos ou casas, onde administrava o vigário encomendado ou colado, seus coadjutores e capelães. Para fiscalizar um distrito ou forania, ou seja, uma reunião de várias paróquias próximas, foi criado o cargo de vigário da vara. 
Por isso, é necessário prestar atenção quando nos referimos à Vila do Príncipe, pois se trata de um espaço de múltiplos poderes seculares e religiosos, locais e provinciais, ligados a outras instâncias de poder e de autoridades. Para o indivíduo comum da Vila do Príncipe do período colonial estes serviços públicos - para o bem e para o mal - estavam todos disponíveis em função de ser capital da Comarca do Serro do Frio, sede de paróquia ou freguesia com seu termo e além disso era uma vila dispondo de Senado da Câmara para administração de seu termo imenso nas primeiras décadas do século XVIII.

Em termos de distâncias territoriais nesse período estamos falando de uma quase impossibilidade de um vigário da vara ou de um vereador do Senado da Câmara conhecer todos os lugares sobre os quais atuava. Não por acaso, com o passar do tempo foram criados os cargos locais para ampliar a rede administrativa da Vila do Príncipe e da comarca com seus funcionários, o que não aconteceu na mesma proporção de rapidez com as paróquias que não podiam delegar padres para se estabelecerem fora de sua matriz, nas filiais. A centralidade da paróquia era ao mesmo tempo uma demarcação de território eclesiástico quando havia padre colado ou fixo, mas muito inflexível e pouco distendido, pois tudo girava em torno dos párocos e seus atendimentos personalizados e normalmente nas vilas a circulação de fieis devotos era maior, assim como de conhecenças, o que atraia cada vez mais os párocos para a sua própria matriz. No caso do primeiro padre colado serrano, Simão Pacheco, quanto mais velho ele ficava em idade, maior a dificuldade de sair em atendimento às filiais. Havia, por isso, um descompasso entre o poder secular e o religioso: o primeiro funcionava com provisões semestrais, anuais, bianuais, trianuais, com a dinâmica das provisões e patentes enquanto um padre colado ficava na sua paróquia desde sua provisão até a morte.

O que nos interessa neste estudo é analisar qual era a autoridade e quais eram as autorizações previstas em regulamentos oficiais de um vigário da vara. Toda forma de autoridade eclesiástica no Brasil no século XVIII foi estabelecida pelo Regimento do Auditório Eclesiástico do Arcebispado da Bahia publicado em 1704, e que antecedeu as Constituições Primeiras do Arcebispado da Bahia de 1707, ambos resultados da preocupação do bispo Sebastião Monteiro da Vide em disciplinar oficialmente o cotidiano ${ }^{1}$ da igreja colonial brasileira.

1 A análise do cotidiano como forma de abordagem da história em escala reduzida e microhistórica. O que seria a microhistória? Narrar eventos históricos a partir do cotidiano dos indivíduos, como eles transitavam seus corpos entre costumes, valores, instituições sociais; como eles conviviam entre si, o que vestiam, o que comiam, como se casavam, se sabiam ler e escrever, como eram sepultados, quais eram seus livros e os objetos e pessoas listados em seus inventários e testamentos post mortem. A microhistória é uma proposta de indagação e revelação das estruturas 
O Regimento do Auditório Eclesiástico do Arcebispado da Bahia disciplinou o funcionamento do Auditório Eclesiástico ou Relação Eclesiástica instalada em Salvador, em 21 de novembro de 1676, com a atribuição de atuar como tribunal de segunda instância, julgando as apelações e agravos das decisões tomadas em primeira instância nas causas em que os bispos ou membros dos juízos eclesiásticos fossem parte (Salgado 119-120). De acordo com o Regimento do Auditório, este era formado por um provisor, vigário-geral, chanceler, desembargadores, juiz dos casamentos, juiz das justificações, juiz dos resíduos, visitadores, vigários da vara, promotor da Justiça, advogados do Auditório, escrivão da câmara, escrivão da chancelaria, escrivães da visitação, notários apostólicos, escrivães do Auditório, meirinho do Arcebispado, escrivão da vara e armas, inquiridor, distribuidor, contador, solicitador da justiça e resíduos, porteiro da Relação e Auditórios, depositário do Juízo e seu escrivão.

Com a publicação do Regimento do Auditório em 1704 e das Constituições Primeiras em 1707, as formas de convivência entre os bispos e seus padres, entre os párocos e seus fiéis devotos e entre os fiéis e suas irmandades e confrarias, ou seja, o que era autorizado e proibido em relação às práticas católicas em território brasileiro foram consagradas em documentos que nortearam o agir desses atores sociais e conduziu os processos cotidianos da distribuição da justiça e dos serviços eclesiásticos.

Assim, o vigário da vara era na Vila do Príncipe (Quadro 1) uma autoridade necessária no organograma da hierarquia eclesiástica e estava prevista em documentos oficiais e sua função era reconhecida como mediadora entre os mandos e desmandos dos padres e párocos, bem como os desajustes religiosos dos fiéis nas suas comunidades. Não é demais recordar que acima do vigário da vara estava o bispo da diocese e que acima do bispo havia o rei a quem cabia a decisão final em muitos casos -dependendo de seus interesses na colônia e da distribuição de privilégio no sistema das mercês-em seus múltiplos tribunais e conselhos, caso fosse o condenado recorrendo nas instâncias menores e suas posses permitissem a contratação de licenciados e advogados. Ao rei, era garantida toda a autoridade, inclusive em aplicações ou não de penas eclesiásticas de último recurso (Hespanha 288). Dessa forma,

No que diz respeito ao poder de justiça eclesiástica, a instância inferior era a vigária da vara eclesiástica, ou comarca eclesiástica,

aparentemente invisíveis, mas que permitiram em algum momento histórico a articulação de experiências individuais e coletivas (Vainfas; Chartier, A história cultural, A história ou a leitura; Ginzburg et al.) 
que tinha como seu representante o vigário da vara, uma vez que o pároco possuía apenas uma função administrativa. $\mathrm{O}$ segundo foro da justiça competia ao tribunal do arcebispado, chamado de Relação Metropolitana, que julgava as apelações e agravos das decisões tomadas pela primeira instância e efetivava os trâmites das causas que envolviam bispos ou membros do juízo eclesiástico. Esse tribunal foi instalado no Brasil logo após a criação do arcebispado da Bahia no ano de 1676 e seu regimento, intitulado "Regimento do Auditório Eclesiástico", constituía juntamente com as Constituições Primeiras do Arcebispado da Bahia as únicas legislações eclesiásticas elaboradas para o Brasil colonial. A última instância do Juízo Eclesiástico cabia, justamente, ao Tribunal Metropolitano de Portugal: a Mesa de Consciência e Ordens (Santos 9).

O vigário da vara era o responsável pela administração da justiça no território das Minas Gerais dentro de sua comarca eclesiástica. O certo é que enquanto na administração civil a capitania mineira era dividida em quatro comarcas (Vila Rica, Rio das Mortes, Sabará e Serro Frio), no governo episcopal ou diocesano o território se encontrava organizado em seis comarcas eclesiásticas: Vila Rica, Rio das Mortes, Rio Verde (que pertencia a jurisdição civil do Rio das Mortes), Sabará, Pitangui (parte da comarca civil de Sabará) e Serro do Frio. Cabia ao vigário da vara fiscalizar administrativamente o cumprimento das obrigações litúrgicas e das normas do direito eclesiástico. Este vigário também chamado de arcipreste ou forâneo tinha mandato especificado em sua duração pela provisão emitida por seu bispo. Eram suas atribuições administrativas "acompanhar os clérigos na sua vida e no exercício de suas funções e velar pela correção das expressões litúrgicas e pela boa administração dos bens eclesiásticos" (Santos 7).

Quadro 1: Vigários da vara da Comarca Eclesiástica da paróquia de Nossa Senhora da Conceição. Vila do Príncipe - 1714-1829

\begin{tabular}{|l|l|l|}
\hline Período & Padre & Título de nomeação \\
\hline $\begin{array}{l}\text { 05/02/1714 a } \\
24 / 06 / 1719\end{array}$ & Antônio Mendanha Souto & Licenciado \\
\hline $\begin{array}{l}\text { 29/06/1719 a } \\
29 / 06 / 1720\end{array}$ & Antônio Pina & $\begin{array}{l}\text { Cônego e mestre-escola do Cabido da } \\
\text { Diocese do Rio de Janeiro }\end{array}$ \\
\hline $\begin{array}{l}17 / 08 / 1721 \text { a } \\
17 / 09 / 1724\end{array}$ & José de Castro Couto & Licenciado \\
\hline
\end{tabular}




\begin{tabular}{|l|l|l|}
\hline $\begin{array}{l}18 / 09 / 1724 \text { a } \\
18 / 01 / 1776\end{array}$ & Simão Pacheco & Licenciado \\
\hline $19 / 06 / 1730$ & Dr. Manuel Tavares Pereira & $\begin{array}{l}\text { Bacharel em Cânones pela } \\
\text { Universidade de Coimbra }\end{array}$ \\
\hline 1755 a 1756 & $\begin{array}{l}\text { Dr. Manuel Cardoso Frazão } \\
\text { Castelo Branco }\end{array}$ & $\begin{array}{l}\text { Bacharel em Cânones pela } \\
\text { Universidade de Coimbra [?] }\end{array}$ \\
\hline 1756 a 1762 & $\begin{array}{l}\text { Dr. Domingos José Coelho } \\
\text { Sampaio }\end{array}$ & $\begin{array}{l}\text { Bacharel em Cânones pela } \\
\text { Universidade de Coimbra [?] }\end{array}$ \\
\hline 1776 a 1785 & Dr. Nicolau da Silva Belo & $\begin{array}{l}\text { Bacharel em Cânones pela } \\
\text { Universidade de Coimbra }\end{array}$ \\
\hline 1785 a 1788 & $\begin{array}{l}\text { Dr. Manuel José da Fonseca } \\
\text { Brandão }\end{array}$ & $\begin{array}{l}\text { Bacharel em Cânones pela } \\
\text { Universidade de Coimbra }\end{array}$ \\
\hline $\begin{array}{l}30 / 05 / 1793 \\
29 / 04 / 1797\end{array}$ & Gregório dos Reis Melo & Mestre de Capela \\
\hline $\begin{array}{l}25 / 03 / 1806 \\
31 / 03 / 1819\end{array}$ & $\begin{array}{l}\text { Francisco Rodrigues Ribeiro } \\
\text { de Avelar }\end{array}$ & Licenciado \\
\hline $\begin{array}{l}01 / 01 / 1821 \text { a } \\
31 / 01 / 1829\end{array}$ & $\begin{array}{l}\text { Dr. Manuel Francisco da } \\
\text { Silva }\end{array}$ & $\begin{array}{l}\text { Bacharel em Cânones pela } \\
\text { Universidade de Coimbra }\end{array}$ \\
\hline
\end{tabular}

Fontes: Arquivo Histórico do Tribunal de Contas de Portugal; Arquivo Nacional da Torre do Tombo; Arquivo Pessoal Maria Eremita de Souza; Briskievicz; Mesquita; Seabra 65-69; Senna 171.

\section{O REGIMENTO DO AUDITÓRIO DE 1704 E O COTIDIANO DA VIGARIA SERRANA}

No Regimento do Auditório, a terminologia "vigário da vara" aparece apenas treze vezes, algumas dentro do mesmo número ou item do ordenamento eclesiástico. Na página 16, fica claro que o vigário da vara era diretamente subordinado ao vigário-geral da sua diocese. Entre os dois a relação era imediata, direta, como fica claro no número 64, que trata das diligências sobre crimes com previsão de deportação para outras partes do Reino português:

Perguntará per si as testemunhas nas causas crimes sendo o delito tal, que provado mereça degredo de Angola, São Tomé, ou daí para cima, e nas querelas e denunciações em todo o caso antes sua pronunciação; e havendo de se dar comissão para se perguntarem, 
por ser o lugar do delito fora da cidade, e tiverem as testemunhas distantes se cometerá ao vigário da vara do distrito, e não o havendo ao pároco mais idôneo, salvo no caso de morte, porque neste irá sempre o vigário-geral, ou outro ministro a que o cometermos com o escrivão a quem tocar, ou nos parecer. E bem assim perguntará as testemunhas nas causas matrimoniais, quando se tratar do vínculo do matrimônio, ou separação quoad thorum e nas de promessas matrimoniais sempre as que assistirão a elas, e na causa cíveis graves, se ou a ele parecer, ou as partes o requererem (Vide, Regimento 16).

O trabalho em equipe composta pelo bispo, o vigário-geral ${ }^{2}$ do bispado e o vigário da vara gerou um importante processo com coleta de depoimentos contra o sargento-mor Felipe Álvares de Almeida da freguesia de Nossa Senhora da Conceição do Mato Dentro em 1760. A acusação conduziu-se nas várias etapas do processo, seguindo todo o ritual previsto nas Constituições de 1707. Nos autos do processo de blasfêmia e falsidade ideológica Felipe Álvares de Almeida dizia-se confessor, ou seja, possuidor das ordens maiores, dados somente aos sacerdotes habilitados em processo de genere et moribus. Entre 1760 e 1762, circularam correspondências entre a Inquisição de Lisboa, o bispo dom frei Manuel da Cruz (primeiro bispo da Diocese de Mariana), a Vigararia Geral de Mariana comandada pelo reverendo dr. Teodoro Ferreira Jácome ${ }^{3}$

2 Segundo Pires 47, “dos livros do Juízo consta que na maioria das vezes o próprio vigário-geral era juiz de casamentos e resíduos, cuidando de assuntos referentes a casamentos, testamentos e inventários. Desde a criação do bispado até o fim do século XVIII, Mariana teve nove vigáriosgerais". Foram eles: o dr. Geraldo José de Abranches foi o primeiro; o dr. José dos Santos foi o segundo vigário-geral, servindo de 16 de maio de 1752 até 14 de julho de 1756; o terceiro foi o dr. Manuel Cardoso Frazão Castelo Branco, que em 1756, já se encontrava de posse da cadeira de arcipestre. No dia 14 de julho desse mesmo ano foi provido no cargo de vigário-geral, ficando até 03 de janeiro de 1761. O quarto vigário-geral foi o dr. Teodoro Ferreira Jácome; o cônego Inácio Correia de Sá foi o quinto; o sexto foi o cônego José Botelho Borges, seguido do dr. José Lopes Ferreira da Rocha, natural da Bahia; o oitavo foi o dr. Francisco Pereira de Santa Apolônia seguido do nono no século XVIII, o dr. Quintiliano Alves Teixeira Jardim.

3 Segundo Rodrigues, "a Vigaria da Vara cumpria um papel importante no envio de casos à Inquisição mesmo que o vigário da vara não fosse Comissário. Os casos que estivessem em andamento naquela instância, ou mesmo os que já tivessem recebido sentença, poderiam ser enviados ao Comissário do Santo Ofício, geralmente os da sede do Bispado e, a partir dele, serem encaminhados para o Tribunal de Lisboa. O promotor da Vigaria da Vara da Vila do Príncipe assim procedeu em 1770 quando denunciou o padre José de Brito e Souza porque, no ato da confissão, tinha o costume de fazer perguntas a respeito dos cúmplices dos casos que lhe eram confessados. A denúncia foi feita ao Comissário de Mariana, João Roiz [Rodrigues] Cordeiro, que após tal procedimento mandou ordem para que tirassem sumário das testemunhas antes de enviar o caso ao Tribunal do Santo Ofício" (53). De fato, o processo contra o padre Brito começou com uma 
e a Vigararia da Vara sob direção do reverendo dr. Domingos José Coelho Sampaio $^{4}$ da comarca eclesiástica da Vila do Príncipe, responsável direta pelos depoimentos do acusado e demais testemunhas, juntando essa devassa aos autos. Felipe Álvares de Almeida ficou preso na cadeia da Vila do Príncipe onde foi interrogado sendo enviado a Vila Rica para ouvir sua sentença. ${ }^{5}$ A carta do bispo ajuntada aos autos do processo expõe o caso em minúcias:

Porque nos cortou com grande mágoa de nosso coração que na freguesia de Nossa Senhora da Conceião do Mato dentro da Comarca do Serro do Frio deste nosso Bispado, sucederam os horríveis casos, que sabidas heresias, e contem blasfêmias heréticas, trazendo várias pessoas e um homem despido e preso pelo pescoço pintando-o para este efeito com tinta vermelha fingindo com este sangue, e levando-o por várias partes especialmente a uma varanda em que o intitularam Ecce Homo; como também se fizera um ajuntamento de homens brancos e outro de pretos para o fim de encomendar as Almas, mas com tais estrondos e sinais ridículos que faziam uma horrenda dissonância e que acumulram várias blasfêmias; e que além do sobredito houvera um secular que esquecido do temor de Deus chegara a fingir-se sacerdote e pároco, confessara e casara várias pessoas: mandamos ao reverendo vigário da vara da dita Comarca aqueles danos para este efeito os nossos poderes tire logo com toda a circunspeção devassa dos sobreditos casos e vendo suficiente prova

denúncia ao vigário da vara padre Dr. Nicolau da Silva Belo, em 19 de outubro de 1769, servindo o padre Brito no arraial do Rio Vermelho, onde o caso aconteceu, sendo ele padre encomendado daquela recém-criada paróquia. O longo processo ouviu muitas testemunhas, mas o padre não foi incriminado (Arquivo Nacional da Torre do Tombo, Inquisição de Lisboa, 1769, fl. 87-102). a 18 de julho de 1762" em que há um lançamento de um lote localizado "do Corte para a Santa Rita João Batista da Silva santeiro parte com Caetano de tal e Domingos José Coelho" (Arquivo Pessoal Maria Eremita de Souza, Caderno 100, n.p.); à fl. 125v. o padre parece regularizar suas terras: "Corte do Conselho para Santa Rita: Domingos José Coelho três braças na rua quem vem do Corte do Conselho para Santa Rita que partem de uma parte com João Batista da Silva santeiro e de outra com quem de direito". Este livro não se encontra mais no Arquivo do Iphan Serro. A braça de terra media 2,2 metros, ou seja, de frente, o lote do padre tinha 6,6 metros.

5 Villalta narra a trajetória dos culpados de maneira diferente, fazendo entender que Felipe Alvares teria sido remetido a Lisboa, para os cárceres do Tribunal do Santo Ofício de Lisboa. Contudo, os documentos mostram que Felipe foi até Vila Rica saindo da Vila do Príncipe e seus comparsas receberam suas admoestações na cadeia serrana. Prova disso é que o tio de Felipe Álvares enviou de Portugal uma petição para o Brasil, denunciando a perseguição dos inimigos da família. Tratase do frei Pedro da Conceição, da Ordem de São Francisco, morador de Lisboa (32-34). 
contra os delinquentes os prenda e sequestre; e concluida a devassa a remeta ao Tribunal competente. Dada neste nosso Palácio Episcopal da Cidade Mariana nos 16 de junho de 1760 sob nosso sinal somente (Arquivo Nacional da Torre do Tombo, Inquisição de Lisboa, 1760, fl. 99).

A sentença não passou de admoestações no sentido de que se evitassem qualquer reptição dos atos contràrios à religião católica. Dessa forma no dia 07 de março de 1762 ficou definida a sentença de Felipe Álvares de Almeida levado à cadeia de Vila Rica para a audiência com a presença de dois de seus familiares. No dia 31 de maio de 1762 foi lavrado um Termo de Admoestação a José Luiz de Sampaio, Paulo José da Cunha e Custódio Ferreira Braga réus presos na cadeia da Vila do Príncipe para que tratassem de viver como católicos e se "abstivesse[m] de atos de galhofa de nossa religião católica" (Arquivo Nacional da Torre do Tombo, 1760, fl. 159-161v.). Ouvir as testemunhas, colher seus depoimentos, escrever partes do processo originando-os ou cumprindo diligências de outros distritos era função do vigário da vara, previsto no número 338:

Quando o juiz dos casamentos não puder per si perguntar às testemunhas, por serem pessoas que se devem perguntar em suas casas, as mandará inquirir pelo inquiridor do juízo com o escrivão, e não sendo moradores na cidade, mandará passar comissão ao vigário da vara do distrito, para as perguntas com o seu escrivão, e fechados, e lacrados seus ditos serão remetidos ao escrivão da Câmara por pessoa fiel, e segura (Vide, Regimento 75).

Havia duas formas de proceder nas diligências: per si ou por delegação. Per si era pessoalmente e por delegação era o efeito de outrem colher os testemunhos. Abaixo do vigário da vara havia o pároco, sua principal fonte de informação. Na paróquia de Nossa Senhora da Conceição vimos anteriormente que o primeiro vigário encomendado também era licenciado a fim de atuar como vigário da vara. O padre Antônio de Mendanha Souto Maior era obrigado por seu ofício a fiscalizar a moral e os bons costumes de seus fregueses e também de outros párocos. Seria natural que o vigário da vara não fosse pároco onde houvesse a sede de sua vara, mas isso não aconteceu na Vila do Príncipe; antes, ao contrário, a regra geral foi a acumulação dos cargos, vigário/pároco e vigário da vara.

Há no Regimento do Auditório importante previsão de como a relação entre pároco e vigário da vara se daria nesse caso, em relação aos pretendentes 
ao sacerdócio, os habilitandos ou ordinandos que, como já vimos anteriormente, deveriam passar pela avaliação do sangue, da vida e dos costumes (genere, vitce et moribus) que se completa em outro número, com praticamente os mesmo termos:

348. E constando ao juiz das justificações pelas informações dos párocos, que o habilitando per si, e seus pais, e avôs, é de limpo sangue sem fama, nem rumor em contrário, e que é de bom procedimento, o mandará examinar em Relação; e achando que mostra capacidade para poder ter préstimo para ser sacerdote, e servir de utilidade à Igreja, the despachará a sua petição, e mandará passar Mandados de segredo, para os párocos das origens informarem da limpeza do sangue, e legitimidade do habilitando, e de sens pais, e avós paternos e maternos, como acima fica dito; e com a informação que derem, nomearão até sete ou oito testemunhas (sem que a parte intervenha, nem tenha noticia disso que sejam pessoas antigas, fidedignas e Cristãs velhas, e não sejam parentas do habilitando. E sendo das freguesias desta Cidade, ou seus subúrbios, as perguntará per si o Juiz das Justificações; e se forem em outra parte do Arcebispado, mandará passar' comissão ao vigário da vara do distrito e não o havendo, ao pároco que lhe parecer de confiança, e experiência, e na comissão irão insertos os interrogatórios abaixo declarados (Vide, Regimento 76-77).

481.Os papeis dos ordenandos, assim de diligências de genere, como de Ordens, e patrimônio, ${ }^{6}$ e todos os mais de segredo da Justiça, os levará per si a nós, ou ao Provisor, quando lhe tocar o despacho deles; e os irá procurar, quando estiverem despachados; e não por mão dos pertencentes, aos quais de nenhuma maneira dirá as diligencias que se fazem, nem o estado delas, senão havendo despacho de que devam ter notícia, ou sendo-lhe por nós, ou pelo Provisor mandado pedir alguma informação para as diligências: $\mathrm{e}$ as comissões que passar para as tais diligencias a algum dos vigários da vara deste Arcebispado, nunca serão remetidas por mão, nem via das partes, antes as remeterá garantir que os futuros sacerdotes tivessem o mínimo de bens e rendimentos para seu sustento. Ao ser obrigado a apresentar seu patrimônio no seu processo de habilitação, o futuro padre João Batista Araújo, serrano de nascimento, foi socorrido por seu padrinho o capitão-mor José Batista Rolim, quem lhe doou uma morada de casas; o seu pai, Lourenço de Azevedo Couto doou-lhe três escravos, e seu Antônio Monteiro Padilha (casado com a irmã do ordinando, Ana Maria Joaquina de Araújo), doou uma chácara por detrás da igreja do Rosário que foi de Manuel Lobo Pereira e possuía por carta de arrematação (Arquivo Pessoal Maria Eremita de Souza, Caderno 3, n.p.). 
por sua via com todo o segredo, à custa dos mesmos pretendentes. E fazendo o contrário o havemos por esse mesmo feito por suspenso do ofício até nossa mercê (Vide, Regimento 106).

Quem nos oferece uma importante relação dos padres ordenados na Vila do Príncipe é o cônego Trindade (1928) quando enumera quantos sacerdotes receberam as ordens maiores na Diocese de Mariana (Quadro 2) - não temos esses dados da Diocese do Rio de Janeiro. Todos esses padres passaram com maior ou menor rigor pela avaliação do vigário da vara da Vila do Príncipe, como era obrigatório pelo regimento eclesiástico.

Quadro 2: Ordenações de padres da Vila do Príncipe - Diocese de Mariana 1758 a 1827

\begin{tabular}{|c|c|c|c|}
\hline \multicolumn{4}{|c|}{ Dom frei Manuel da Cruz } \\
\hline 1 & 24 de fevereiro de 1758 & Alexandre Carlos Salgado & $109 *$ \\
\hline 2 & 24 de setembro de 1762 & Manuel Ferreira de Carvalho & 214 \\
\hline \multicolumn{4}{|c|}{ Dom frei Domingos da Encarnação Pontevel } \\
\hline 3 & 21 de setembro de 1782 & Antônio da Costa Freire & 9 \\
\hline 4 & 19 de fevereiro de 1785 & Cipriano Pires Pardinho & 22 \\
\hline 5 & 28 de março de 1789 & Felipe Coelho da Fontoura & 72 \\
\hline 6 & 18 de junho de 1791 & Antônio Manuel de Mendonça Cabral & 102 \\
\hline \multicolumn{4}{|c|}{ Dom frei Cipriano de São José } \\
\hline 7 & 17 de dezembro de 1808 & Antônio Joaquim de Sousa & 48 \\
\hline 8 & 22 de dezembro de 1810 & João José Dias de Camargos & 63 \\
\hline 9 & 19 de dezembro de 1812 & Bernardino de Senna Camargo & 91 \\
\hline 10 & 20 de maio de 1815 & João Germano [da Silva] & 107 \\
\hline 11 & 20 de maio de 1815 & Manuel Bento da Paixão & 111 \\
\hline \multicolumn{4}{|c|}{ Dom frei José da Santíssima Trindade } \\
\hline 12 & 24 de maio de 1823 & João de Sousa Pereira Lins & 28 \\
\hline 13 & 24 de maio de 1823 & Manuel Gonçalves Nunes & 33 \\
\hline 14 & 24 de maio de 1823 & José Jacintho Nunes & 36 \\
\hline 15 & 03 de maio de 1824 & Justiniano Pereira da Cunha & 45 \\
\hline 16 & 26 de fevereiro de 1825 & Antônio Joaquim Vieira & 66 \\
\hline 17 & 01 de novembro de 1826 & Joaquim José de Vasconcelos Perpétuo & 83 \\
\hline
\end{tabular}




\begin{tabular}{|l|l|l|l|}
\hline 18 & 01 de novembro de 1826 & Antônio Alves da Paixão & 84 \\
\hline 19 & 01 de novembro de 1826 & Antônio Gonçalves Nunes & 85 \\
\hline 20 & 25 de março de 1827 & José Pereira de Santa Paula [Bárbara] & 96 \\
\hline
\end{tabular}

* Ordem numérica de padres ordenados por cada bispo na sua lista cronológica. Não são relacionadas ordenações dos bispos dom Joaquim Borges de Figueroa (1771-1772) e dom Bartolomeu Manuel Mendes dos Reis (1772-1777).

Fonte: Trindade.

Outra função importante do vigário da vara era conferir os testamentos e inventários post mortem quando neles houvesse alguma doação para a igreja, bem como deveria conferir se as missas previstas e pagas pelo testamenteiro tinham, de fato, sido rezadas conforme o último desejo dos falecidos. Assim, previa o número 380 :

Quando algum testamenteiro, ou herdeiro agravar, ou apelar de algum dos nossos vigários da vara para a nossa Relação sobre a execução, e conta do testamento que perante ele estiverem dando, o Juiz dos Resíduos será o relator e lindo o incidente do agravo, tornará ao vigário, e procederá nela como em tudo o mais pertencente à execução do testamento; e o nosso Juiz dos Resíduos desta Cidade nunca poderá avocar a si as causas e contas dos testamentos, que aos nossos vigários da vara pertencerem conforme a seus Regimentos (Vide, Regimento 84).

Contudo, é no Título IX que encontramos registrado os ofícios pertencentes aos vigários da vara. O número 399 informa o motivo da constituição do ofício desses vigários e qual o seu perfil exigido: letrado, uma vez que obrigatoriamente devia saber ler e escrever para ler cartas, regimentos e ordens, além de escrever suas decisões e acrescentar seus escritos aos processos; pessoa de bom entendimento, prudente, virtuoso e exemplar, pelo menos, indicando a falta da figura do bacharel em direito formado na Universidade de Coimbra (neste caso, provavelmente, o cargo dado seria de vigário-geral), necessitando provisionar o vigário da vara como licenciado, como já vimos no caso do padre Antônio de Mendanha Souto Maior. Para o cargo de vigário da vara era preciso, em poucas palavras, saber ler e escrever e ter comportamento exemplar. Assim previa o número 399: 
Para que os bispos possam executar com maior diligência aquelas cousas, que devem para com seus súditos, e mais vigilantemente satisfazer as obrigações de seu pastoral ofício, é necessário que deputem, e constituam vigários da vara em alguns lugares de sua Diocese. Sendo possível, serão letrados, ou pelo menos pessoas de bom entendimento, ${ }^{7}$ prudência, virtude, e bom exemplo, como é bem que tenham para o tal cargo; os quais em sendo providos por nós, e tendo provisão ou carta passada pela Chancelaria, jurarão perante nós, ou nosso Chanceler nla forma costumada, e sem isso não poderão servir e somente servirão enquanto for nossa vontade (Vide, Regimento 90).

O vigário da vara deveria, por conta de seu ofício, dominar perfeitamente dois códigos - o Regimento do Auditório e as constituições de sua diocese (normalmente as Constituições Primeiras do Arcebispado da Bahia) - sem o qual poderia ter seus atos anulados. O número 400 indica as funções específicas desse cargo:

Nas causas de que conhecerem, assim por razão de ofício, como por lhes serem especialmente cometidas, guardarão as Constituições e a ordem Regimento do Auditório Eclesiástico, e oficiais da Justiça, em todas as causas que aos vigários da vara se puderem aplicar, e acomodar; e o que fizerem contra nossas Constituições, será nulo, e de nenhum vigor; e para que saibam algumas cousas, que a seu oficio pertencem; e por nossas Constituições lhes são concedidas, declaramos as seguintes:

1. Poderão tirar devassas, (nos casos em que se devem tirar) e receber denunciações, e fazer sumários dos sacrilégios cometidos nos lugares sagrados, ou contra clérigos das freguesias de sua jurisdição, que gozem do privilegio do foro; e remeterão as ditas devassas, e sumários ao nosso vigário-geral para os pronunciar como for justiça.

Parece que era comum no início do século XVIII o despreparo quase total dos sacerdotes para lidar com questões mais complexas para o sistema do padroado real. Dessa forma, explica Trindade os motivos possíveis da má formação deste clero: "atirado ao mundo sem formação espiritual que o mantivesse à altura dos seus compromissos, porque não tivera seminário; sem amor ao estudo que o entretivesse, porque apenas iniciado nas letras, sem estímulos que lhe soerguessem o moral quando por ventura abatido, porque pouco virtuosa a sociedade do seu tempo, ainda assim soube cumprir seu dever e preencher sua missão" (37-38). 
2. Poderão proceder contra as pessoas que lhes forem desobedientes em qualquer matéria de seu oficio, fazendo auto, e cometendo o perguntar das testemunhas (citada a parte) a alguma pessoa idônea; e se ajuntará fé do escrivão se estiver presente; e eles ditos vigários determinarão, e apelarão em lodo ocaso, e mandarão a apelação a nosso vigários geral com a brevidade possível.

3. Tomarão contas dos testamentos que pela alternativa, e concordata pertencerem aos meses do Juízo Eclesiástico, que são janeiro, março, maio, julho, setembro e novembro, fazendo executar pontualmente a vontade dos testadores, dando apelação, ou agravo para a nossa Relação.

4. Poderão passar monitórios, e dar sentenças em causas sumárias da ação de dez dias, ou de juramento d'alma até a quantia de dez mil réis; e darão sempre apelação, e agravo para a nossa Relação.

5. Querendo alguns forasteiros casar, poderão fazer sumários de testemunhas, e tirar os depoimentos, e os remeterão ao nosso juiz dos casamentos para os sentenciar.

6. Poderão fazei perguntas aos contraentes e confessando eles os esponsais, os julgarão por esposados de futuro, e mandarão que corridos os bandos, e não havendo impedimento se recebam em termo de trinta dias, e entretanto mandarão que a noiva seja depositada em alguma casa honesta, e o depositário assignará termo em que se sujeita ao juízo Eclesiástico, debaixo do juramento que lhe será dado.

7. Poderão fazer sumários de sevícias, ou de nulidade de matrimônio para efeito de ser depositada a mulher (havendo perigo de continuar no consórcio); porém sempre a causa se tratará perante o nosso vigário-geral.

8. Poderão e devem obrigar aos casados no Reino ausentes por mais de três anos, ou aos que nos limites de sua jurisdição viverem apartados de suas mulheres sem causa justa, e aprovada por nossa Relação, ou vigário-geral, a que vão para o consórcio, usando para este efeito das censuras eclesiásticas, sendo necessário.

9. Poderão reconciliar as Igrejas da sua jurisdição que por alguma causa forem violadas, ou polutas, mas não se forem sagradas por algum bispo.

10. Poderão condenar até quantia de uma pataca, (conforme a contumácia e escândalo) aos que trabalharem aos Domingos, e dias Santos de guarda, havendo porém respeito à necessidade da obra, e da pessoa: e aplicarão as condenações ás fábricas 
das igrejas donde forem fregueses os culpados, os quais se não quiserem pagar, serão evitados dos Ofícios Divinos.

11. Poderão absolver de todos os casos a nós reservados e dispensar no foro interno aos ligados por cópula ilícita para poderem pedir o débito não sendo, porém o impedimento contraído antes do matrimônio, ou sendo no primeiro grau, ou no segundo.

12. Poderão fazer autos contra os que usurpam a nossa jurisdição, ou sejam eclesiásticos, ou regulares, isentos ou seculares, e remeterão os ditos autos ao nosso vigário-geral.

13. Poderão proceder contra qualquer pessoa, que sem licença nossa, ou de nosso promotor, dada por escrito, tirarem esmolas gerais ou particulares disserem missas, pregarem, ou levantarem altar; e isto ainda que sejam regulares que pretendam ter esta faculdade.

14. Poderão determinar as dúvidas que ocorrerem acerca dos lugares, e precedências, assim nas procissões como dentro nas igrejas, conservando cada um na sua posse, reservando-lhes seu direito, para alegarem perante o nosso vigário-geral.

15. Poderão dar licença (com parecer de alguns clérigos aptos) para se enterrarem em sagrado aquelas pessoas, em que pede haver dúvida.

16. Poderão mandar pagar os ofícios, esmolas de missas, e ofertas que se deverem aos clérigos, guardando a forma de direito.

17. Poderão fazer com o juiz ordinário todas as imunidades das igrejas, fazendo que os que a elas se aceitarem não sejam tirados delas ou de seus adros (salvo em custódia) antes de ser julgada a dita imunidade.

18. Serão obrigados a ter além das Constituições do Arcebispado, este Regimento do Auditório e proverão que os seus oficiais o guardem em tudo inteiramente. E além do que nele está disposto, farão os vigários da vara tudo o mais que em nossas Constituições lhes está mandado (Vide, Regimento 90-92).

O Regimento do Auditório de 1704 previu dezoito obrigações para a função eclesiástica do vigário da vara. Uma qualidade deste vigário devia ser o de não causar problemas para a diocese, sem permitir a relaxação dos costumes paroquiais. A vida das pessoas nas primeiras décadas do século XVIII, ou seja, nas minas do Serro do Frio e sua Vila do Príncipe de 1702 até 1750, era toda uma atuação social marcada pela teatralização dos costumes, pela aparência ou exteriorização do gesto social colonial. Viver era disfarçar. Conviver era aparentar virtudes e bons costumes, o que era comum na vida cotidiana, ou em público. A vida privada não seguia essa mesma linha de comportamento. 
Por isso, o jeito barroco serrano de ser do Antigo Regime é vasado na performance pública, no exagero das aparências. Tudo era muito exagerado, causando efeito imediato: os padres eram contratados para fazerem sermões espetaculares nas festas oficiais; os cortejos cívico-religiosos eram carregados de símbolos de poder e de autoridade, sejam eles das irmandades ou do Senado da Câmara; a Semana Santa era um evento que pretendia reproduzir a morte de Jesus Cristo quase perfeitamente, o que tornava o gesto exagerado, falseado, rebuscado, público e por isso, barroco.

Não é para menos que a coroação do rei e rainha da festa do rosário nos seus primeiros anos causava comoção popular ao teatralizar um costume africano - este gesto veio com os escravizados para as minas serranas - causando grande repercussão na comunidade por inverter ou afrontar teatralmente a ordem social estabelecida. É que o homem barroco serrano era o que Ávila 51 definiu como aquele "criador da vontade de arte e do impulso lúdico [...], a concretização do que poderíamos denominar uma grande e vital vontade estética lúdica". O jeito barroco serrano de ser é vasado, então, na imaginação teatralizada do jogo social invertido ou não, na luta entre a vida e a morte, entre a opulência e a pobreza, enfim, numa constante fantasia (Ávila 51) de estar no mundo, ou como já vimos, entre dois mundos - a cidade dos homens e a cidade de Deus.

$\mathrm{O}$ vigário da vara se fez uma figura fundamental entre duas instituições que se completavam no sistema do padroado, a coroa portuguesa e a Igreja católica, a primeira com sua estrutura de poder e autoridade baseada no Senado da Câmara, comarca, capitania, Governo-geral e sua sede em Lisboa; a segundo performando quase da mesma forma seu poder e autoridade com suas paróquias, comarcas eclesiásticas, dioceses e arcebispados com sua sede em Roma. Dessa maneira, de acordo com Martins:

As vigararias da vara faziam parte de um esforço coordenado para a montagem de uma cadeia de comunicação entre as regiões mais distantes e periféricas com os centros diocesanos, cujos pontos de contato se articulavam entre paróquia - vigararias da vara - e vigararia geral. Pela forma de dispersão de sua jurisdição no território colonial, o poder episcopal no século XVIII era de grande serventia ao Santo Ofício, que mesmo com a ausência de um Tribunal da Fé na América portuguesa, se fez presente não só por meio das Visitações e pela rede de agentes do oficialato inquisitorial, mas também por meio de uma malha colaborativa entre o aparato eclesiástico colonial e o Tribunal de Lisboa; [...] quando o número de agentes 
inquisitoriais na América portuguesa ainda era consideravelmente fraco, o Santo Ofício escolheu se corresponder com os eclesiásticos seculares locais e com clérigos regulares, principalmente os jesuítas. Desta forma, gerou-se uma 'corrente de transmissão' de denúncias entre os agentes eclesiásticos e inquisitoriais, sintonizando as duas esferas em um universo colaborativo que perduraria até o século XIX (27-28).

Podemos destacar alguns documentos relativos à função do vigário da vara nos primeiros anos da Vila do Príncipe, antes mesmo da criação da Comarca do Serro do Frio, em 1720. No dia 16 de agosto de 1719, o governo da Capitania de São Paulo e Minas do Ouro enviou carta para Gaspar Vaz Cardoso, chamando a sua atenção para a reclamação dos oficiais do Serro do Frio sobre o excesso de jurisdição que se arrogava, não permitindo que eles praticassem atos em correição em Mato Dentro e Conceição e, por causa disso, recomendou-lhe abster-se desse proceder não saindo fora do âmbito de suas atribuições (Revista do Arquivo Público Mineiro 576). Em Conceição do Mato Dentro, já havia uma paróquia e a disputa pela jurisdição do território gerou uma crise que a princípio para envolver o Senado da Câmara da Vila do Príncipe e o capitão do distrito. Mas não era apenas isso: os oficiais serranos estavam reclamando da correição impossibilitada ao vigário da vara padre Antônio de Mendanha Souto Maior. Houve um estremecimento das relações eclesiásticas - não sabemos o motivo da não aceitação da correição na paróquia - entre o vigário da vara serrano e Gaspar Vaz Cardoso. Fato é que saiu vitorioso o vigário da vara que impugnou a jurisdição de Gaspar Vaz Cardoso no distrito da Conceição, insubordinado à autoridade do padre Souto Maior, respaldada pelo Senado da Câmara da Vila do Príncipe (Revista do Arquivo Público Mineiro 576). Outra situação constrangedora para o vigário da vara da Vila do Príncipe envolveu a catequese e o batismo de escravos pelos párocos. Em carta de 23 de setembro de 1719 o rei enviou uma carta aos vigários das Minas Gerais dizendo estar:

Desgostosíssimo ante as notícias que tem do grande número de escravos que vivem e morrem nas Minas sem batismo; por isso the ordenou a 29 de abril recomendasse a todos os párocos verificar os escravos que estão por catequizar e batizar em suas freguesias chamando-os ao grêmio da santa fé e fornecendo lista aos ouvidores das comarcas para que estes procedam contra os senhores recalcitrantes (Revista do Arquivo Público Mineiro 582-583). 
Outra questão complicada de se revolver no contexto das minas de ouro e da escravidão africana crescente gerou uma carta régia datada de 26 de novembro de 1719 endereçada a todos os vigários da vara das minas gerais recomendando o cumprimento do bando ou ordem de 23 de novembro de 1719. A querela dizia respeito à obrigatoriedade de que para se batizar e celebrar matrimônios os escravos eram obrigados a apresentar somente homens brancos, obrigados pelo bando a cumprir a ordem, a fim de se "evitar a subordinação de uns a outros, até agora praticada por via desses sacramentos e consequentemente enfraquecer o poder que os negros iam adquirindo contra os brancos manda que igual recomendação seja feita a todos os párocos das Minas" (Revista do Arquivo Público Mineiro 605). Talvez por isso era comum nos primeiros registros da paróquia de Nossa Senhora da Conceição que batismos e matrimônios fossem oficializados com a presença dos homens brancos e suas esposas (Pinto 762). Teria esse bando originado a ideia tipicamente brasileira de que madrinha e padrinho devem ser opulentados, ofertando aos seus afilhados bons presentes e boa reputação futura? A forma de convivência colonial se espalhou por tantos espaços da convivência social, se espalhou no interior da cultura popular e sedimentou costumes e hábitos aparentemente banalizados, naturalizados, típicos, que sua origem se perdeu muitas vezes no tempo de práticas muito antigos.

Aos vigários da vara cabiam as devassas contra aqueles denunciados por práticas avessas aos ensinamentos da Igreja (Quadro 3).

Quadro 3: Fluxo de uma denúncia no período colonial

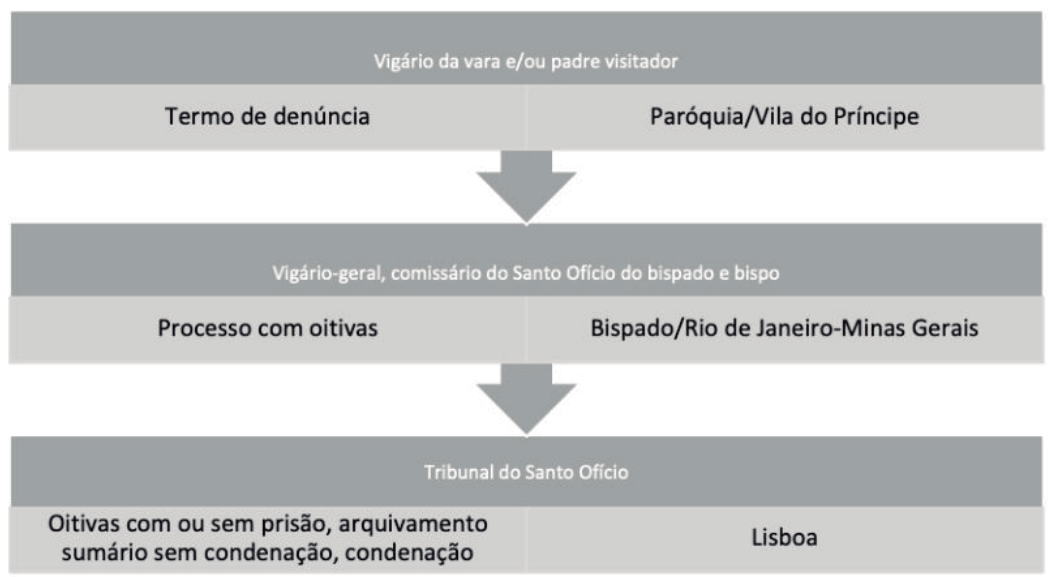

Fonte: Elaboração pessoal do autor. 


\section{PROCESSOS SERRANOS APURADOS PELO VIGÁRIO DA VARA}

Vejamos o caso de uma diligência realizada no arraial do Tijuco que se tornou uma denúncia séria contra um grupo de escravos e forros. Trata-se do rapto com agressão realizado por um feitiço contra José Francisco Pacheco, homem de boa vida, morador do Ribeirão da Arca, no sítio da Palmira, em $1^{\circ}$ de junho de 1738 , com denúncia formalizada no dia 10 do mesmo mês. O acontecido foi escrito no papel, depois remetido Senado da Câmara da Vila do Príncipe, posteriormente encaminhado ao vigário da vara e esse o fez chegar ao vigáriogeral da Diocese do Rio de Janeiro que o remeteu para o Tribunal do Santo Ofício em Lisboa, possivelmente apenas para dar conhecimento e ser arquivado. Não há como saber o que se aconteceu depois da diligência, possivelmente uma admoestação pessoal para os envolvidos, lavrando um termo e colhidas as assinaturas originais, a rogo ou em sinal da cruz. A denúncia seguinte mostra como as autoridades da época lidavam com os desacatos dos escravos, bem como o que é mais importante - a denúncia de feitiçaria e rapto, seguida de agressões:

Meu Senhor! Como vossa mercê me encarregou de aguar diligências do Serro Frio nesta Comarca do Serro, que agora remeto, e dou conta do que nela [...] me faz também preciso noticiar a vossa mercê quem no Sítio do Palmira, distrito do arraial da Gouveia, próximo do Tijuco, freguesia da Vila do Príncipe, se acham algumas pessoas presas com fama de feiticeiras, as quais são Eugenia Maria, negra forra, da nação Mina, e uma sua escrava chamada Severina da mesma nação; Joana da Silva, forra, também Mina, e Ana Carvalho, conhecida mais por alcunha de "Repolho", da mesma nação, moradora na grupiara de São Patrício da mesma freguesia e Bernardo Mina, escarvo de Antônio Pereira Machado, morador do Ribeirão da Arca, da mesma freguesia. Como também Francisco Mina preto velho, forro, como aleijão em uma mão, sem domicílio certo, e por hora residente na Tapera, freguesia da Conceição do Matro Dentro, da dita Serro.

A causa que houve para se vir neste conhecimento foi que na noite do primeiro de junho deste ano, estando José Francisco Pacheco, homem de boa vida e costumes, em casa do sargento-mor José da Costa Souza, onde é morador, por nesse dia deu com um açoite na escrava Severina de Eugenia Maria acima declaradas, vieram as didtas negras a casa do dito José da Costa, e da cama em que estava José Francisco o levaram sem ele sentir, e em distância de três quartos de légua, onde lhe trataram com pancadas em tal forma 
que no outro dia ele precisou muito recolher-se à casa, aonde já procuravam pela falta que dela se havia; pois se achava na ocasião com moléstia que o empedia sair fora do sítio em que era morador. Este declaro, que me veio declarar o sargento-mor José da Costa Souza para o participar a vossa mercê, nomeando portanto que podem ter notícia do fato, e José Ribeiro Lopes, Francisco Ribeiro maior, Manuel Ferreira Antônio, Teodósio Pereira, Marcelino Pereira da Rocha, Antônio Carvalho, todos moradores do Ribeirão da Arca, freguesia da Vila do Príncipe (Arquivo Nacional da Torre do Tombo, Inquisição de Lisboa,1738, fl. 70-70v.).

No dia 07 de novembro de 1742, outra curiosa denúncia foi escrita de próprio punho e dirigida ao vigário da vara, comissário do Tribunal Santo Ofício. Suzana, negra, moradora do Morro do Pilar, na freguesia de Nossa Senhora da Conceição do Mato Dentro, havia feito um feiticiço há quatro ou cinco anos atrás a fim de curar um negro, num ritual de cachoeira, com queima de folhas de bananeira e um pedido para que o doente pulasse por cima da fogueira. $\mathrm{O}$ que chama a atenção na denúncia é a sua popularidade, parecendo ser comum o conhecimento de como fazê-la efetivametne, pois Luiz Pereira Pacheco fez sua queixa da parte de Suzana começando por citar sua residência, depois relatando os fatos e ao final pedindo providências, de maneira bastante habitual (Arquivo Nacional da Torre do Tombo, Inquisição de Lisboa, 1742, fl. 267-267v.).

Em 30 de abril de 1747, Jacinto Teixeira Leite encaminhou ao desembargador José da [...] Brandão um denúncia com tom de reclamação:

Denuncio e dou parte a vossa mercê que vim as minas do Serro do Frio em junho de 1746, cheguei à cidade do Rio de Janeiro e me arranchei em umas casas junto da praia que são de Sebastião Gurgel de Amaral, junto com Gaspar Dias da Silva, morador do arraial do Tijuco no mesmo Serro do Frio [...] conversando comigo, digo e o dito que diz que existem ][...] ele conversando comigo me disse que a causa de naquela terra terra haverem [...] por que os engenhos que nela se foram feitos por cristãos novos e algum dia se degredaram para o Rio de Janeiro e que como depois foram presos pelo Santo Ofício e confiscados pelo dito rematados por cristãos velhos que, por isso não davam mais nada porque eram usurpados de seus donos que com que [...] o Santo Ofício podia possuir aquilo que não era seu. Também disse que estava na cidade um mulato filho de Antônio Lopes de Leão e cristão novo e morador na Vila do Ouro Preto das 
Minas Gerais que vinha de Roma ordenado cérigo; e dizendo-lhe eu como ó pudera ordenar sendo filho de cristão novo, respondeu o dito que tomara ele [...] termos [...] feito de cristão velho [...]. Também me disse Manoel Pereira de Meireles morador no arraial do Tijuco, caixeiro que foi do alferes Antônio Gonçalves Campos contando eu o que o dito Daspar Dias da Silva me disse; quem também a ele lhe dissera vindo das Minas Gerais a mesma cidade, Izidório Mendes de Carvalho morador no dito Tijuco [...] (Arquivo Nacional da Torre do Tombo, Inquisição de Lisboa, 1747, fl. 141).

A queixa acima de Jacinto Teixeira Leite parece confusa e difusa, pois contém uma reclamação de um terceiro sobre engenhos que apesar de terem sido confiscados ou sequestrados de cristãos novos continuavam dando prejuízo. Contudo, a segunda denúncia de um padre mulato ordenado em Roma filho de cristão novo é muito interessante, pois como vimos anteriormente, o Rio de Janeiro era um dos territórios de grandes fazendas de cristãos novos no Brasil que de lá partiam para aumenarem seus ganhos nas minas de ouro, como possivelmente fez o padre Antônio de Mendanha Souto Maior. Trata-se, pois, de caso muito conhecido no Rio de Janeiro à época, pois havia se espalhado entre os "homens bons" ou nobres e cristão velhos do lugar. O padre mulato da Vila Rica devia estar negociando com o bispo da Diocese do Rio de Janeiro o recebimento de uma paróquia e o caso caiu na boca do povo, ou melhor, da nobreza do lugar. Talvez por isso a denúncia. Havia, nesse periodo ainda como reflexo das políticas do governo português de perseguição aos judeus, muitas intrigas entre os cristão velhos e os cristãos novos, com rumores e denúncias, sequestros de bens e muitas queixas. A situação mostrado pelo denunciante contudo, mostra que os bispos do Rio de Janeiro eram bastante condenscendentes com os cristãos novos, aparecendo como protetores dos mesmos em vários contextos, como o da ordenação do viúvo, o padre Antônio de Mendanha Souto Maior. São intrincadas redes de autoridades e autorizações, próprias das negociações políticas do gesto colonial. Dessa maneira, por mais que houvesse uma denúncia, se o bispo não quisesse dar prosseguimento era muito simples: não abria diligência, não oficiava os vigário da vara, enfim, o assunto acabava apenas arquivando-se em livro do promotor as denúncias. Em relação à circulação das informações no Brasil colonial é importante destacar que a denúncia escrita ao Santo Ofício foi parar em mãos de oficiais do tribunal em Lisboa, tendo sido protocolada no Rio de Janeiro por um visitante mineiro que soube de casos relativos ao Tijuco e à Vila Rica, indicando uma ordenação realizada em Roma, envolvendo marranos e cristãos velhos. Havia uma rede de informações, usada de maneira 
regular pelas autoridades governamentais. Por isso, não era incomum a traição por denúncia nas tratativas das sedições, das revoltas e das conjurações, cujo maior exemplo é Joaquim Silvério dos Reis. A questão central é saber o que o denunciante ganhava com suas informações, se bens materiais, cargos ou influência nas estruturas de poder. Há que se lembrar que não havia, ainda, o crime de denunciação caluniosa, especialmente quando se tratava de cristãos novos, hereges, blasfemos e feiticeiros.

Assim, outra denúncia em texto minúsculo merece nossa atenção por revelar o gesto colonial eclesiástico e o papel que os tribunais da Igreja exerciam nesse período. No dia 12 de abril de 1748, Francisco Ferreira preto, escravo de José Pereira de Carvalho, capitão do navio Nossa Senhora do Bom Despacho e São José que estavam embarcados no Rio de Janeiro entrando nesta cidade na:

Lua nova dos pescadores veio a esta Mesa no dia 12 de abril de 1748 denunciar preto, escravo chamado Antônio não sabe de que, nem de quem é escravo, só que é morador no Serro do Frio, não sabe em que paragem, qual the deu uma raiz de uma erva que não sabe seu nome dizendo-lhe que se seu senhor lhe quisesse dor a metesse na boca e cuspisse fora porque logo este seu senhor havia de desistir do intento (Arquivo Nacional da Torre do Tombo, Inquisição de Lisboa, 1748, fl. 243).

A intenção que moveu o capitão do navio até a Mesa para fazer sua denúncia provavelmente se liga à ideia de que um mal menor - uma erva para mudar o intento do senhor de escravos - podia serguir-se um poder maior ainda sobre outros proprietários de escravos, o que poderia ser um grande mal para uma sociedade escravista. Não sabemos onde o contato entre o escravo marinheiro e o escravo Antônio do Serro do Frio se deu, se no Rio de Janeiro - o escravo Antônio podia estar fazendo companhia ao seu senhor em algum empreendiento - ou em algum lugar da Comarca do Serro do Frio onde por acaso o escravo marinheiro estivesse levando alguma mercadoria. Fato é que a denúncia breve parece também ter um aspecto pedagógico: obrigar o escravo envolvido a contar o caso e ter que ficar de frente de uma autoridade eclesiástica servia como uma punição pelo ocorrido e que deveria ser evitado das próximas vezes. O escravo marinheiro devia, então, aprender que se tratava de feitiçaria e que não seria mais aceito tal comportamento.

No Rio do Peixe, uma denúncia de feitiçaria e pacto com o diabo contra Manuel Correia Lobo, branco, foi assentada no dia 24 de abril de 1753 por denúncia de José Gonçalves Goya, pardo. O processo foi iniciado na paróquia 
de Nossa Senhora da Conceição do Mato Dentro, chegou até ao vigário da vara da Comarca Eclesiástica da Vila do Príncipe, foi levada para a Diocese de Mariana e de lá recebeu um novo encaminhanto. Em 16 de maio de 1753, o padre João Álvares da Costa, vigário colado da paróquia de Nossa Senhora da Conceição do Mato Dentro do Serro do Frio foi autorizado a tirar um sumário das testemunhas sobre a denúncia, o qual deveria ser tomado "com todo o segredo e circunspecção everiguando se o denunciado adora ao demônio e lhe depreca, tendo-o por mestre, e juntamente se diz, ou crê alguma cousa contra a nossa Santa Fé" (Arquivo Nacional da Torre do Tombo, Inquisição de Lisboa, 1753, fl. 212). No dia 22 de outubro de 1753, a oitiva das testemunhas iniciou-se pela escolha do escrivão o padre Manuel Gonçalves da Silva, morador da Ponte do Rio das Pedras, distrito de Itapanhoacanga. A primeira testemunha do processo ouvida foi Antônio de Oliveira, com idade em torno de 20 anos, cumpadre do denunciado Manuel Correia Lobo.

Antônio de Oliveira prestou juramento aos santos evangelhos e disse que "somente sabia pelo ouvir dizer que nem bala nem faca lhe havia de fazer mal e que disso se tratava publicamente a todos" (Arquivo Nacional da Torre do Tombo, Inquisição de Lisboa, 1753, fl. 213). Ele não sabia ler e escrever e por isso fez um sinal da cruz no lugar de sua assinatura no interrogatório. Outra testemunha, Albano Moreira, homem pardo, casado e morador no arraial de Conceição do Mato Dentro, com loja ou tenda de ferreiro, com idade em torno de 40 anos. Depois do juramento, o oficial mecânico afirmou que o denunciado costumava dizer abertamente "que não temia nada, nem espingarda, nem bacamartes e alguns dias antes tinha o denunciado mostrado a ele testemunha vários facadas em uma vestia que trazia vestida, gabando-se de que não chegaram ao corpo, sucedidas no arraial de Tapanhuacanga" (Arquivo Nacional da Torre do Tombo, Inquisição de Lisboa, 1753, fl. 214). Esta testemunha sabia ler e esecrever, assinando seu depoimento.

No dia 21 de outubro de 1753, outro termo de ajuntada, dessa vez o depoimento de outra testemunha, Francisco de Brito Roriz, homem branco, casado, mercador com loja, morador de Conceição do Mato Dentro, com idade de 32 anos. Ele apenas confirmou o que outros já haviam dito: "e perguntado ele testemunha pelo conteúdo da denúncia [...] ouvira dizer que lhe deram homens facadas no arraial de Tapanhuacanga que lhe não fizeram mal e que era de má vida, capaz de fazer os excessos que contém a denúncia" (Arquivo Nacional da Torre do Tombo, Inquisição de Lisboa, 1753, fl. 214v.).

No dia 27 de outubro de 1753, foram ouvidas outras testemunhas: José Gonçalves Goya, homem pardo, morador do Rio do Peixe, 25 anos, vivendo em casa de sua mãe que afirmou que o denunciado "disse repetidas vezes que não 
temia quaisquer armas que viessem contra ele, nem ainda os mesmos diabos do inferno, que neste e em outras ocasiões publicamente se falava de as armas não entrarem com ela mostrando uma vestia que havia vestido com algumas facadas" (Arquivo Nacional da Torre do Tombo, Inquisição de Lisboa, 1753, fl. 215). Ele sabia ler e escrever, assinando o documento. Seguiram-se os depoimentos de André Ferreira Guimarães, morador do arraial de Itapanhoacanga, homem branco, solteiro, de 40 anos que afirmou nada saber sobre a denúncia que se apresentava contra Manuel Correia Lobo, a não ser que trazia ao pescoço uma bolsa de conteúdo desconhecido. No mais, ouviu dizer da valentia do denunciado. Assinou o termo. Depois dele apresentou-se Gerônimo Pereira de Matos, homem pardo, casado, morador do arraial de Tapanhuacanga, nada acrescentando de novo, assim como Inácio da Costa, homem pardo, solteiro, morador da Tapanhuacanga. Ele também assinou o termo. Acabaram-se as oitivas e lavrado um termo no dia 06 de janeiro de 1754 pelo vigário-geral da Diocese de Mariana a fim de que o bispo desse seu parecer (Arquivo Nacional da Torre do Tombo, Inquisição de Lisboa, 1753, fl. 217v.). Tudo leva a crer que o processo foi enviado à Inquisição de Lisboa apenas para arquivamento. O diabo, caso estivesse pactuado com o denunciado, conseguiu daquela vez passar ileso do Santo Ofício e das mãos do Tribunal Eclesiástico da Diocese de Mariana.

Em 1756, Paulo Gil, pardo forro, morador dos arrabaldes da Vila do Príncipe foi também acusado de feitiçaria, sendo-lhe atribuídas mortes, com desconfiança de ter feito pacto com o demônio (Arquivo Eclesiástico da Arquidiocese de Mariana, Livro de Devassas, 1756-1757, fl. 50-52). Enamorado de uma escrava, Paulo Gil recebeu a negativa de sua proprietária e ambas acabaram adoecidas, só melhorando depois de exorcismos do padre. ${ }^{8}$ Segundo Souza:

Quem nos dá depoimento detalhado sobre as feitiçarias de Paulo Gil é João Batista, pardo forro de vinte anos. O feiticeiro o interpelara "se queria ter mandinga para ninguém poder com ele", oferecendolhe pedra d'ara ${ }^{9}$ moída para se beber em infusão. João Batista 1757, fl. 97), é registrada uma denúncia contra Violante Coutinho, moradora de São Gonçalo, em Paraúna de Andréquicé, por fazer danças e calundares em sua casa onde negros tocavam atabaques. Por esta época, em 1755, no arraial de Conceição do Mato Dentro foi denunciado Antônio, preto, por feitiçaria e adivinhação, por curar pessoas de seus males (Arquivo Nacional da Torre do Tombo, Inquisição de Lisboa, 1755, fl. 109).

9 Assim como o pelourinho representava a fundação de uma vila com seu concelho no século XVIII, a pedra d'ara era o sinal da consagração do templo católico, benta solenemente, ao centro do altarmor, onde deferia pousar as espécies, ou seja, a hóstia e o vinho durante a consagração ritualística 
recusou, mas Paulo Gil continuou insistindo por mais oito dias; por fim, aquiesceu, acompanhando o feiticeiro numa excursão noturna até certa encruzilhada, onde ficou sozinho enquanto Paulo Gil se ausentava por pouco tempo. Voltou momentos depois acompanhado de sete ou oito figuras negras, todas de forma humana, dizendo: "Aqui estão os nossos amigos". Apavorado, João Batista disse ao feiticeiro que ia se retirar um instante, mas que voltaria logo; sumiu, enfiando-se em casa. Tornando a encontra-lo, Paulo Gil o repreendeu asperamente, dizendo que fizera muito mal em desaparecer; insistiu mais uma vez na mandinga, sem que João Batista se decidisse. Dias depois, dormia quando acordou com forte dor no quadril: Paulo Gil o ferira para tirar seu sangue e dá-lo aos "amigos", que em troca lhe asseguravam força desmesurada. João Batista renegou dos amigos, não os queria como tais. Imediatamente, sobreveio um redemoinho terrível, e o rapaz, apavorado, pôs-se a chamar por sant'Ana. Desde então, nunca mais falou com Paulo Gil (338-339).

\section{CONCLUSÃO}

O vigário da vara atuava cotidianamente na freguesia de Nossa Senhora da Conceição da Vila do Príncipe, capital da Comarca do Serro do Frio. Se por um lado havia o ouvidor que zelava especificamente pela ordem da sua comarca, coube ao vigário da vara o ordenamento de sua comarca eclesiástica. Pautado pelo Regimento do Auditório de 1704 a atuação deste vigário se ajustava ao esquema de ordenamentos da governança eclesiástica colonial, tendo acima de si apenas o vigário-geral e o bispo da diocese. Nesse caso específico, o vigário da vara era responsável direto por colher queixas em relação aos costumes relaxados, prezando pela pedagogia moralizadora dos ensinamentos da Igreja. Essa proximidade com os fiéis devotos auxiliava na fiscalização da vida dos paroquianos.

O vigário da vara morava na Vila do Príncipe, mas sua atuação ia muito além dos limites geográficos da capital da Comarca do Serro do Frio. Onde quer que houvesse necessidade de efetivar oitivas e colher testemunhos sobre os problemas religiosos da freguesia serrana, lá estava o vigário da vara. Por conta

para sua transformação em corpo e sangue de Cristo. A sua fixação no altar-mor representava o erguimento de uma capela fixa. Era comum que os padres andassem com uma pedra d'ara para apoiar as espécies quando em templos muito provisórios, as ermidas. 
de sua atuação, percebemos claramente as disposições moralizadores e punitivos coloniais, ligados à noção de que todo mal deveria ser revelado e confessado não importando a quem o processo pudesse privar da liberdade, caso houvesse ordem de prisão.

Portanto, o vigário da vara atuava de maneira muito próxima dos paroquianos, interferindo na conduta disciplinada e moralizante da Igreja católica no território serrano. A autoridade deste vigário era tamanha que seu processo iniciado em lugares desconhecidos da Coroa portuguesa podia culminar em prisão ordenada pela Inquisição de Lisboa, com deportação do acusado para colher seu testemunho na capital portuguesa. Isso demonstra que no interior do sistema do padroado real a autoridade religiosa e eclesiástica do vigário da vara se confundia com a autoridade secular e estatal dos oficiais do Senado da Câmara, produzindo um duplo efeito coercitivo e disciplinar na população local, em que ser súdito e católico se amalgamavam, podendo a punição por algum ato imoral provir de uma das instituições ou de ambas ao mesmo tempo.

\section{REFERÊNCIAS BIBLIOGRÁFICAS}

Arquivo Eclesiástico da Arquidiocese de Mariana. Livro de Devassas, 17561757.

Arquivo Nacional da Torre do Tombo. Inquisição de Lisboa. Denúncia de Francisco Paim da Câmara contra o padre José de Brito e Souza por perguntar na confissão o nome dos cúmplices, 1769, fl. 87-101v. Arraial do Rio Vermelho, Cód. PT-TT-TSO-IL-030-0319.

Arquivo Nacional da Torre do Tombo. Inquisição de Lisboa. Sumario contra Fellipe Alz. de Almeida e outros, 1760, fl. 94-161v., Conceição do Mato Dentro.

Arquivo Nacional da Torre do Tombo. Inquisição de Lisboa, 1753, fl. 217v.

Arquivo Nacional da Torre do Tombo. Inquisição de Lisboa, Denúncia contra Antônio, preto, por feitiçaria e adivinhação, por curar muitas pessoas de malefícios, 1755, fl. 109, Antônio Dias, freguesia de Nossa Senhora da Conceição, Cód. PT-TT-TSO-IL-030-0306.

Arquivo Nacional da Torre do Tombo. Inquisição de Lisboa. Denúncia de Francisco Pereira, preto, escravo do capitão José Pereira de Carvalho [navio Nossa Senhora do Bom Despacho e São José] contra Antônio, preto, escravo, morador do Serro do Frio, 1748, fl. 243, Rio de Janeiro [Serro do Frio], Cód. PT-TT-TSO-IL-030-0298. 
Arquivo Nacional da Torre do Tombo. Inquisição de Lisboa. Denúncia de Luiz Pereira Pacheco [?] contra Suzana, negra, por feitiçaria e adivinhação, 1742, Morro do Pilar, Cód. PT-TT-TSO-IL-030-0296.

Arquivo Nacional da Torre do Tombo. Inquisição de Lisboa. Reclamação sobre engenhos sequestrados de cristãos novos no Tijuco e denúncia de padre mulato ordenado em Roma, filho de cristão novo Antônio Lopes de Leão, 1747, fl. 141, Rio de Janeiro [Tijuco], Cód. PT-TT-TSO-IL-030-0301.

Arquivo Pessoal Maria Eremita de Souza. Cadernos. Caderno [100] 14-04-1984 Tilibra Árvores, n.p.

Ávila, Affonso. O lúdico e as projeções do mundo barroco. Perspectiva, 1971.

Briskievicz, Danilo Arnaldo. A arte da crônica e suas anotações: história das Minas do Serro do Frio à atual cidade do Serro em notas cronológicas. (14/03/1702 a 14/03/2003). Revolução E-book - Simplíssimo, 2017.

Chartier, Roger. A história cultural: entre práticas representações. DIFEL, 1990. ---. A história ou a leitura do tempo. Autêntica, 2009.

Ginzburg, Carlo, et al. A micro-história e outros ensaios. Difel, 1989.

Hespanha, António Manuel. "O poder eclesiástico: aspectos institucionais". História de Portugal. v. 4: O Antigo Regime (1620-1807), director José Mattoso, Estampa, 1993, pp. 287-290.

Martins, Natália Ribeiro. De Portugal às Minas do Ouro: a trajetória do cristãonovo Diogo Nunes Henriques (1670-1729). 2015. 160 fl. Dissertação (Mestrado Acadêmico) - Universidade Federal de Juiz de Fora, Instituto de Ciências Humanas, Programa de Pós-Graduação em História, 2015.

Mesquita, Sônia Nunes, e Maria da Glória Seabra. Paróquia do Serro. História de fé. Edição das Autoras, 2013.

Pinto, Luiz Antônio. "Memórias municipaes. Arquivo da Câmara Municipal da Villa do Príncipe hoje cidade do Serro". Revista do Arquivo Público Mineiro, no. IV, ano I, pp. 755-797, 1896.

Pires, Maria do Carmo. Juizes e infratores: o tribunal eclesiástico do Bispado de Mariana (1748-1800). Annablume, 2008.

Revista do Arquivo Público Mineiro. "Provisões, Patentes e Sesmarias 17171721". Revista do Arquivo Público Mineiro, ano XXIV, 1933 (Códice 12 da Seção Colonial do Arquivo Público Mineiro).

Rodrigues, Aldair Carlos. Sociedade e inquisição em Minas colonial: os familiares do Santo Oficio (1711-1808). 2007. 241fl. Dissertação (Mestrado) - Universidade de São Paulo, São Paulo, 2007. https://doi.org/10.11606/d.8.2007.tde-22102007-112714

Salgado, Graça (coord.). Fiscais e meirinhos: a administração no Brasil colonial. Nova Fronteira, 1985. 
Santos, Fabrício Forcato dos. A nódoa da luxúria sob a batina: confrontos entre clérigos seculares e paroquianos na Vila de Paranaguá no século XVIII. Revista Ágora, no. 8, 2008, pp. 1-30.

Senna, Nelson Coelho de. "Traços biographicos de serranos ilustres, já fallecidos, precedidos de um bosquejo histórico sobre a fundação da cidade do Serro (Minas Gerais)". Revista do Instituto Histórico e Geográfico Brasileiro, t. LXV (2 ${ }^{\mathrm{a}}$ parte), 1903, p. 333-374.

Souza, Laura de Mello e. O diabo e a Terra de Santa Cruz. Feitiçaria e religiosidade popular no Brasil colonial. 2. ed., Companhia das Letras, 2014.

Trindade, Raimundo. Archidiocese de Marianna. Subsídios para a sua história. Escolas Profissionais do Lyceu Coração de Jesus, 1928.

Vainfas, Ronaldo. Os protagonistas da história: micro-história. Campus, 2002. Vide, Sebastião Monteiro da. Constituições Primeiras do Arcebispado da Bahia. Edusp, 2010 [1707].

---. Regimento do Auditorio Ecclesiastico, do Arcebispado da Bahia, Metropoli do Brasil e da sua Relação, e Officiaes da Justiça Ecclesiastica, e mais cousas que tocão ao bom governo do dito Arcebispado. Typographia 2 de dezembro de Antônio Louzada Antunes, 1853 [1704].

Villalta, Luiz Carlos. "A igreja, a sociedade e o clero". História de Minas Gerais. As minas setecentistas 2, organizadores Maria Efigênia Lage de Resende, e Luiz Carlos Villalta, Autêntica; Companhia do Tempo, 2007, pp. 25-57. 